УДК 347.736

DOI https://doi.org/10.32837/pyuv.v0i2(31).559

\author{
А. Й. Бучинська \\ orcid.org/0000-0001-6348-299X \\ кандидат юридичних наук, \\ доцент кафедри правознавства \\ Житомирського національного агроекологічного університету
}

\title{
БАНКРУТСТВО ФІЗИЧНИХ ОСІБ ЗА ЗАКОНОДАВСТВОМ УКРАЇНИ ТА ПОЛЬЩІ
}

Традиційно банкрутство, під яким слід розуміти визнану господарським судом неспроможність боржника відновити свою платоспроможність за допомогою процедури санації та реструктуризації та погасити грошові вимоги кредиторів не інакше, ніж через застосування ліквідаційної процедури, більшою мірою стосувалося суб'єктів господарювання. Однак не лише суб'єкти господарювання, але і фізична особа може потрапити у складне фінансове становище з надзвичайних і незалежних від неї причин, таких як, наприклад, хвороба, нещасний випадок, втрата роботи тощо.

Тривалий час, а саме починаючи з 1992 р., банкрутство в Україні регулювалося з позиції фінансової неспроможності суб'єктів господарювання задовольнити вимоги кредиторів, можливого пошуку шляхів відновлення їх платоспроможності. Однак нестабільність валютного ринку, недосконалість чинного законодавства призводить до того, що фізична особа з незалежних від неї причин (коливання курсу валют) не в змозі задовольнити вимоги кредиторів. Тому з метою захисту як боржника, так і кредиторів із 21 жовтня 2019 р. в українському законодавстві запроваджено інститут банкрутства фізичних осіб, закріплений у Кодексі з процедур банкрутства, який визначає умови та порядок відновлення платоспроможності боржника.

Польський законодавець запровадив інститут банкрутства фізичних осіб 5 грудня 2008 р. шляхом внесення змін до Закону «Про банкрутство» від 28 лютого 2003 р. Основною метою запровадження цього інституту було обмеження соціального відчуження та створення фізичним особам, котрі не здійснюють підприємницьку діяльність, можливості для подальшого життя без обтяжень.

I йдеться не про автоматичне списання наявної заборгованості у фізичної особи, яка в силу життєвих обставин виявилася неплатоспроможною, $\mathrm{a}$, якщо це буде можливе, про задоволення вимог кредиторів (а оскільки, такими кредиторами найчастіше виступають банки, то і максимальний захист їхніх інтересів). Тому, на думку польських дослідників, першочерговою й основною метою банкрутства фізичних осіб необхідно вважати зменшення або часткове чи повне погашення боргів [1, с. 25-26]. Подібний підхід підтримують українські науковці, підкреслюючи, що в зако- нодавстві про неспроможність насправді йдеться не про врятування боржника, а про забезпечення майнових інтересів кредиторів шляхом максимального задоволення саме їхніх вимог [2, с. 53].

Необхідно зазначити, що в український юридичній літературі не проведено жодних досліджень регулювання банкрутства фізичних осіб у польському праві, а оскільки через євроінтеграційні процеси у громадян України та Польщі можуть виникнути питання щодо неплатоспроможності фізичних осіб, вважаємо за необхідне дослідити законодавство двох держав у цій сфері.

Відповідно до ст. 115 Кодексу з процедур банкрутства (далі - Кодекс) сам боржник - фізична особа у разі виникнення обставин, які вказують на його неплатоспроможність, звертається із заявою до господарського суду про відкриття провадження у справі про свою неплатоспроможність. Кредитор у жодному разі не може ініціювати банкрутство фізичної особи.

Господарський суд може прийняти заяву у боржника про відкриття провадження у справі про неплатоспроможність лише за наявності обставин, перелік яких визначено Кодексом і які підтверджують, що боржник не в змозі здійснювати грошові платежі, тобто якщо він постав перед загрозою неплатоспроможності [3, ст. 115]. Слід погодитися з тим, що Кодекс не дає відповіді на питання, чи може бути підставою для відкриття провадження у справі про неплатоспроможність фізичної особи лише один із факторів, зазначених у ст. 115 Кодексу, чи потрібна виключна сукупність всіх факторів, визначених у статті [4, с. 178].

Українське законодавство передбачає процедуру відновлення платоспроможності боржника шляхом запровадження плану реструктуризації боргу фізичних осіб. Реструктуризація може бути запроваджена протягом 120 днів із дня відкриття провадження у справі про неплатоспроможність, у ході якої боржник може дійти згоди із кредиторами щодо зміни строків виплат чи продажу частини майна задля задоволення їхніх вимог. Як зазначає O.M. Бірюков, при розробці плану реструктуризації боргів мають застосовуватися такі способи розв'язання проблем заборгованості: зменшення вимог, прощення боргу, а також припинення зобов'язання шляхом заміни первісного зобов'язання іншим [5, с. 64]. 
Однак щодо реструктуризації боргів фізичної особи український законодавець запровадив певні обмеження, зокрема не підлягають реструктуризації борги боржника щодо сплати аліментів, страхових внесків на загальнообов'язкове державне пенсійне та інше соціальне страхування, відшкодування шкоди, завданої каліцтвом, тощо [3, ст. 125]. Не реструктуризуються також борги за кредитами, отриманими на відпочинок, розваги, придбання предметів розкоші тощо. Крім цього, діють обмеження щодо строку проведення реструктуризації, оскільки виконання плану реструктуризації боргів не може перевищувати 5 років. У разі погашення боргів за іпотечними кредитами строк виконання плану не може перевищувати 10 років. У разі виконання боржником плану реструктуризації боргів господарський суд закриває провадження у справі, а боржник вважається звільненим від боргів.

Якщо в ході розгляду справи про неплатоспроможність фізичної особи не було застосовано реструктуризацію боргів, має місце визнання боржника банкрутом і запровадження процедури погашення боргів. Погашення відбувається за рахунок коштів, виручених від реалізації ліквідаційної маси боржника. До «ліквідаційної маси» належить усе майно боржника, що перебуває у його власності, окрім житла, яке є єдиним місцем проживання сім'ї боржника (квартира загальною площею не більше $60 \mathrm{~m}^{2}$ або житловою площею не більше $13,65 \mathrm{~m}^{2}$ на кожного члена сім'ї боржника чи житловий будинок загальною площею не більше $120 \mathrm{~m}^{2}$ ). Окрім того, не включаються до ліквідаційної маси кошти, які перебувають на рахунках боржника у пенсійних фондах і спеціальних фондах соціального страхування.

До ліквідаційної маси не належить майно, вказане у Переліку майна, на яке не може бути звернуто стягнення відповідно до ст. 55 Закону України «Про виконавче провадження» (наприклад, предмети щоденного побутового особистого вжитку, лікарські засоби тощо) [6]. Досліджуючи проблеми формування ліквідаційної маси боржника-фізичної особи, Л.М. Білецька зазначає, що не вирішеним залишається питання щодо можливості включення до конкурсної маси майна, яке надмірно обтяжене; пов'язане з його особистістю; зовсім вилучене з цивільного обороту [7, с. 56].

Польські науковці також при визначенні складників ліквідаційної маси звертають увагу на те, що не можуть до неї входити предмети особистого вжитку, на які не може бути звернуто стягнення згідно із Цивільним процесуальним кодексом Польщі. Порушується питання про те, що арбітражний керуючий повинен ознайомитися з боржником і оцінити не лише його потреби, але і потреби членів його родини; взяти до уваги його професію, стан здоров'я, освіту та інші обставини, безпосередньо пов'язані з його особою [8, с. 97-98].

Після завершення процедури погашення боргів боржника та закриття провадження у справі про неплатоспроможність приймається рішення про звільнення боржника - фізичної особи від боргів, крім боргів, що виникли з відшкодування шкоди, завданої каліцтвом, іншим ушкодженням здоров'я або смертю фізичної особи; сплати аліментів тощо.

I хоча фізична особа, визнана банкрутом, звільняється від більшості боргів, існує обов'язок такої особи протягом 5 років із моменту визнання її банкрутом перед укладенням договору позики, кредиту, застави або поручительства попереджати в письмовому порядку про факт своєї неплатоспроможності інші сторони таких договорів, також протягом 5 років після визнання фізичної особи банкрутом не може бути відкрито провадження у справі про неплатоспроможність за її заявою, крім випадку, якщо боржник погасив усі борги в повному обсязі. Така особа на 3 роки втрачає свою бездоганну ділову репутацію [3, ст. 135].

Розпочати процедуру банкрутства щодо боржника - фізичної особи, за польським законодавством, можливо у разі їі неплатоспроможності. Боржник є неплатоспроможним, якщо він втратив здатність виконувати свої грошові зобов'язання. Вважається, що боржник втратив здатність виконувати свої грошові зобов'язання, якщо затримка виконання грошових зобов'язань перевищуе три місяці [9, ст. 4912]. Порушити справу про банкрутство фізичних осіб, котрі не провадять господарську діяльність, може лише сам боржник. 3 цією метою він звертається із заявою до Господарського відділення банкрутства районного суду за місцем проживання.

Водночас польський Закон «Про банкрутство» (далі - Закон) визначає випадки, коли суд відмовляє боржнику у порушенні справи про банкрутство фізичної особи, а саме якщо боржник своїми діями спричинився до власної неплатоспроможності або внаслідок умислу чи внаслідок грубої недбалості значно збільшив її ступінь, а також якщо протягом 10 років до дня подачі заяви: 1) щодо боржника проводилася процедура банкрутства і провадження у справі було припинено 3 інших причин, ніж за заявою боржника; 2) встановлений для боржника план погашення вимог кредиторів не був виконаний; 3) боржник, маючи такий обов'язок, всупереч положенням закону не звернувся у встановлений строк із заявою про порушення справи про банкрутство; 4) юридичні дії боржника були визнані такими, що спрямовані на завдання шкоди кредиторам, за винятком випадків, коли провадження у справі обгрунтоване міркуваннями справедливості або гуманними цілями $\left[9\right.$, ст. $\left.491^{4}\right]$. 
Слід підкреслити, що провадження у справах про банкрутство у всіх випадках призводить до втрати всіх накопичених активів, оскільки, як зазначено у ст. 61 зазначеного Закону, в день оголошення банкрутства активи банкрута переходять у ліквідаційну масу, яка служить задоволенню вимог кредиторів банкрута. Однак із цього правила є виняток: якщо до складу майна банкрута входить квартира або односімейний будинок, у якому проживає банкрут, і необхідно задовольнити житлові потреби банкрута та його утриманців, із суми, отриманої від їх продажу, банкруту відокремлюється сума, що відповідає середній орендній платі житла в цій або ж сусідній місцевості на період від 12 до 24 місяців [9, ст. $491^{13}$ ].

На відміну від українського законодавця, котрий спочатку врегулював відновлення платоспроможності боржника шляхом реструктуризації боргів, а потім окреслив процедуру визнання боржника банкрутом і введення процедури погашення його боргів, хоча зрозуміло, що рішення про те, яку з названих процедур застосувати, є прерогативою кредиторів, польський законодавець спочатку врегулював процедуру погашення боргів перед кредиторами.

В ухвалі про затвердження плану погашення вимог кредиторів суд визначає, в якому обсязі та в який строк, але не більше 36 місяців, банкрут зобов'язаний сплатити зобов'язання, визнані згідно з переліком вимог кредиторів, не виконаних у процесі провадження на підставі плану погашення вимог кредиторів, і в якій частині зобов'язання банкрута, що виникли до дати оголошення його банкрутом, будуть припинені після виконання плану погашення вимог кредиторів [9, ст. $\left.491^{15}\right]$.

Зобов'язання, які виникли після оголошення банкрутства і не виконані в ході провадження, враховуються у плані погашення вимог кредиторів у повному обсязі, i їх погашення може бути розстрочене на термін, що не перевищує передбаченого на виконання плану погашення вимог кредиторів. Законодавець у ст. $491^{15}$ зазначеного Закону гарантував: у період виконання плану погашення вимог кредиторів не допускається порушення виконавчого провадження щодо заборгованості, яка виникла перед затвердженням плану погашення вимог кредиторів, за винятком вимог, що виникають на підставі зобов' язань щодо сплати аліментів, непрацездатності, каліцтва, смерті, штрафів тощо [9, ст. $\left.491^{21}\right]$.

Після виконання банкрутом зобов'язань, встановлених планом погашення вимог кредиторів, суд ухвалює рішення про затвердження виконання плану погашення вимог кредиторів і припинення зобов'язань банкрута, які виникли до дати оголошення банкрутства і не виконані внаслідок виконання плану погашення вимог кредиторів.
У разі, коли особиста ситуація банкрута чітко вказує на те, що він не в змозі здійснити жодних виплат за планом погашення вимог кредиторів, суд може визнати заборгованість банкрута безнадійною, і тоді не ухвалюється план погашення вимог кредиторів [10].

Суд за власною ініціативою або за заявою арбітражного керуючого чи кредитора, заслухавши банкрута, арбітражного керуючого, а в разі необхідності - також кредиторів, припиняє провадження у справі, якщо банкрут не вкаже або не передасть арбітражному керуючому всього майна, необхідних документів або належним чином не виконуватиме своїх обов'язків [9, ст. $\left.491^{21}\right]$.

I хоча у польському праві фактично йдеться про оголошення фізичної особи-боржника банкрутом і ухвалення плану погашення вимог кредиторів, домовленість між банкрутом і кредиторами може мати місце за заявою банкрута [11, с. 35], але це відбувається в ході здійснення процедури погашення боргів боржника, і спрямована така домовленість на уникнення реалізації майна боржника, зокрема його житла.

Незважаючи на те, що оголошення банкрутства багатьом здається єдиним правильним рішенням, коли фізична особа неспроможна погашати борги, слід зазначити, що банкрутство може мати негативні наслідки для самої фізичної особи. Наприклад, можуть виникати обмеження щодо укладення такою особою цивільних договорів тощо.

Наслідком банкрутства фізичної особи може бути той факт, що в ситуації, коли фізична особа - банкрут раптово і без належної підстави припинить свою професійну діяльність, вона може ризикувати тим, що буде припинене судове провадження у справі про банкрутство. Внаслідок цього у майбутньому будь-яке звільнення з боргу буде неможливе. Така фізична особа також буде виключена з реєстру неплатоспроможних боржників у Реєстрі національних судів Польщі.

Врегулювавши банкрутство фізичних осіб, польський законодавець, з одного боку, зняв боргове навантаження з боржника, який є неплатоспроможний, шляхом зменшення або часткового чи повного погашення боргів, а з іншого - захистив кредитора шляхом розстрочки та/або відстрочки погашення боргів боржником.

Таким чином, проведений аналіз законодавства України та Польщі з питань банкрутства фізичних осіб дає підстави стверджувати, що загалом має місце подібність законодавчого врегулювання цього інституту з деякими відмінностями. Так, і український, і польський законодавець наділив правом звертатися до суду із заявою про відкриття провадження у справі про неплатоспроможність лише боржника, тобто кредитори жодним чином не можуть ініціювати такого провадження. Надалі саме суд вирішує, чи від- 
кривати провадження у справі про неплатоспроможність фізичної особи, чи ні. Український законодавець визначив обставини, наявність яких є підставою для відкриття провадження у справі про неплатоспроможність фізичної особи (наприклад, розмір прострочених зобов'язань боржника перед кредитором (кредиторами) становить не менше 30 розмірів мінімальної заробітної плати), натомість польський законодавець вказує на обставини, які є підставою для відмови у відкритті провадження у справі про неплатоспроможність фізичної особи (наприклад, боржник своїми діями спричинився до власної неплатоспроможності), тобто маємо певні відмінності в законодавстві двох країн у підході до відкриття провадження у справі про неплатоспроможність фізичної особи. У ході розгляду справи про неплатоспроможність фізичної особи в українському праві можливе прийняття рішення про схвалення плану реструктуризації боргів боржника або запровадження процедури погашення боргів боржника, в польському законодавстві має місце оголошення фізичної особи банкрутом і затвердження плану погашення вимог кредиторів, під час виконання якого боржник і кредитор можуть дійти порозуміння щодо розстрочки та/або відстрочки погашення боргів боржником.

\section{Jimepamypa}

1. Rafał Adamus. Upadłość osoby fizycznej nieprowadzącej działalności gospodarczej. Kwartalnik Okręgowej Izby Radców Prawnych w Katowicach. 2015. № 2 (6). C. $25-34$.

2. Грабован Л. Правовий статус кредиторів за Кодексом України з процедур банкрутства. Підприємни uтво, господарство і право. 2019. № 10. С. 52-60.

3. Кодекс України 3 процедур банкрутства від 18 жовтня 2018 р. Відомості Верховної Ради. 2019. № 19. Ст. 74 .

4. Застосування норм Кодексу України з процедур банкрутства : збірка наукових статей / за заг. ред. С.В. Жукова. Київ : Алерта, 2019. 216 с.

5. Бірюков O.M. Банкрутство громадян: за і проти. Бюлетень Міністерства юстищї України. 2011. № 11. C. 60-65. URL: http://nbuv.gov.ua/UJRN/bmju_ 20111112 (дата звернення: 17.06.2020).

6. Закон України «Про виконавче провадження» від 2 червня 2016 р. Відомості Верховної Ради. 2016. № 30. Ст. 542.

7. Сучасні виклики та актуальні проблеми судової реформи в Україні: Матеріали II Міжнар. наук. практ. конф. (Чернівці, 18-19 жовтня 2018 р.); редкол. : О.В. Щербанюк, А.С. Цибуляк-Кустевич та ін. Чернівці, 2018. $392 \mathrm{c}$

8. Medyński M., Szczepkowska B. Skład masy upadłości i dopuszczalne potracenia w postepowaniu upadłościowym konsumenta. Doradca Restrukturyzacyjny. 2016. № 6 (4). C. 97-103.

9. Ustawa z dn. 28.02.2003 r. Prawo upadłościowe. Dz.U. 2003 № 60 poz. 535.

10. Marcin Sysiak. Upadłość konsumencka - postępowanie upadłościowe wobec osób fizycznych nieprowadzacych działalności gospodarczej (wybrane zagadnienia). URL: file://C:/Users/777/Desktop/tematy/ стаття \% 20банкрутство/Upadlosc konsumencka.pdf (дата звернення: 25.02.2020).

11. Kuźnik M. Konsumencka zdolność upadłościowa - zakres podmiotowy. Studia Ekonomiczne. Zeszyty Naukowe Uniwersytetu Ekonomicznego w Katowicach. 2015. № 240. S. 34-45.

\section{Анотація}

Бучинська А. Й. Банкрутство фізичних осіб за законодавством України та Польщі. - Стаття.

У статті досліджуються нормативно-правові підстави застосування процедури банкрутства до фізичних осіб за законодавством України та Польщі. Проведений аналіз дає підстави стверджувати, що і в українському, і в польському законодавстві, врегульовуючи процедуру банкрутства фізичних осіб (споживче банкрутство), законодавець, з одного боку, зняв боргове навантаження з боржника, який $є$ неплатоспроможний, шляхом зменшення або часткового чи повного погашення боргів, а з іншого - захистив кредитора шляхом розстрочки та / або відстрочки погашення боргів боржником. Досліджуючи законодавство України та Польщі 3 питань банкрутства фізичних осіб, можна стверджувати, що загалом має місце подібність законодавчого врегулювання цього інституту, хоча напевно можна зауважити і про деякі відмінності у регулюванні цих правовідносин. Зокрема, і український, і польський законодавець наділив правом звертатися до суду із заявою про відкриття провадження у справі про неплатоспроможність лише боржника, і саме суд приймає рішення, чи відкривати провадження у справі про неплатоспроможність фізичної особи, чи ні. Відмінності простежуються у прийнятті рішення про відкриття провадження у справі про неплатоспроможність фізичної особи: так, український суддя керується підставами, які визначив законодавець і наявність яких становить підгрунтя для відкриття такого провадження, натомість польський законодавець вказує на обставини, що є підставою для відмови у відкритті провадження у справі про неплатоспроможність фізичної особи. Український законодавець запровадив процедуру відновлення платоспроможності боржника шляхом реструктуризації боргів та окреслив процедуру визнання боржника банкрутом і введення процедури погашення його боргів. Рішення про те, яку з названих процедур застосувати, належить кредиторам. У польському праві фактично йдеться про оголошення фізичної особи - боржника банкрутом і ухвалення плану погашення вимог кредиторів, домовленість між банкрутом і кредиторами може мати місце, але це відбувається в ході здійснення процедури погашення боргів боржника, і спрямована така домовленість на уникнення реалізації майна боржника, зокрема його житла.

Ключові слова: банкрутство, неплатоспроможність, фізична особа, боржник, банкрут, кредитор, погашення боргів.

\section{Summary}

Buchynska A. Y. Bancruptcy of natural person by the legislation of Ukraine and Poland. - Article.

The article examines the legal basis for applying for bankruptcy proceedings against natural persons under the laws of Ukraine and Poland. The analysis gives grounds to assert that in both Ukrainian and Polish legislation regulating the bankruptcy procedure of individuals (consumer bankruptcy), the legislator on the one hand removed the debt burden from the debtor, which is insolvent, by reducing or partial or full repayment of debts, and on the other - protected the creditor by installments 
and/or deferral of debt repayment by the debtor. Examining the legislation of Ukraine and Poland on bankruptcy of natural persons, it can be argued that in general there are similarities in the legislative regulation of this institution, although we can probably see some differences in the regulation of these legal relations. In particular, both the Ukrainian and Polish legislators have given the right to apply to the court to initiate insolvency proceedings only against the debtor, and it is the court that decides whether or not to open insolvency proceedings against an individual. Differences can be traced in the decision to open insolvency proceedings against an individual, so the Ukrainian judge is guided by the grounds determined by the legislator and the existence of which is the basis for opening such proceedings, while the Polish legislator indicates the circumstances that are grounds for refusing to initiate proceedings. case of insolvency of an individual. The Ukrainian legislator introduced a procedure for restoring the debtor's solvency by debt restructuring and outlined the procedure for declaring the debtor bankrupt and introducing a procedure for repaying his debts, the decision on which of these procedures to apply belongs to creditors. In Polish law, it is actually a matter of declaring a natural person-debtor as bankrupt and approving a plan to repay creditors' claims, an agreement between the bankrupt and creditors may take place, but this takes place during the debtor's debt repayment procedure, in particular, their dwelling.

Key words: bankruptcy, insolvency, natural person, debtor, creditor, debt repayment. 